\title{
Le Flâneur du tiers monde: diri, liyan, dan kisah perjalanan dalam Bon Voyage Monsieur Le Président!
}

\author{
Novi Kurniawati ${ }^{1} \mid$ Moh Atikurrahman $^{2}$
}

${ }^{1}$ Prodi Sastra Perancis Universitas Negeri Semarang

${ }^{2}$ Prodi Sastra Indonesia

UIN Sunan Ampel Surabaya

\author{
Correspondence: \\ Novi Kurniawati \\ Prodi Sastra Perancis \\ Universitas Negeri Semarang \\ novikurniawati@mail.unnes.ac.id
}

Article History:

Received 04 June 2021

Revised 17 June 2021

Accepted 20 June 2021

\begin{abstract}
Unlike other subgenres, travel writing aims to emphasize objectivity in work exploration. In addition to convincing the reader, travel writing wants to emphasize that the reference is reality, not fiction or mere fabrication. This paper tends to analyze the motives of travelogues in Bon Voyage Monsieur Le Président. The story is one of Gabriel García Márquez's travel stories, collected in the Douze Contes Vagabonds. The twelve pilgrim tales revolve around one's experience of traveling from the Third World to the First World, the Europe. Indeed, the roots of travel records come from the representation of the West over the East as a travel report in the activities of European colonialism. However, the short-stories in the Douze Contes Vagabonds must be understood as counter-travel, because the narrator's subject (travelers) here, by using travelogue as a modus operandi, come from the Third World.

Keywords:

Sastra perjalanan, travel writing, flâneur, flânerie, Gabriel García Márquez.
\end{abstract}

\section{Abstrak}

Tidak seperti subgenre lain, sastra perjalanan hendak menegaskan narasi objektif dalam eksplorasi pengkaryaan. Selain untuk meyakinkan pembaca, sastra perjalanan ingin menekankan jika acuannya adalah realitas, bukan fiksi atau fabrikasi semata. Tulisan ini bertendensi untuk menganalisis motif perjalanan dalam Bon Voyage Monsieur Le Président. Cerita tersebut merupakan salah satu cerita perjalanan Gabriel García Márquez yang terkumpul dalam Douze Contes Vagabonds. Dua belas cerita dalam kumpulan tersebut berkisah tentang pengalaman melancong seseorang dari Dunia Ketiga ke Dunia Pertama, Eropa. Sejatinya akar dari catatan perjalanan berasal dari representasi Barat atas Timur sebagai travel report dalam aktivitas kolonialisme Eropa. Sehingga kisah-kisah perjalanan dalam Douze Contes Vagabonds harus dipahami sebagai counter-travel, karena subjek pencerita (pelancong), dengan menggunakan kelana sebagai modus operandi, berasal dari Dunia Ketiga.

Kata Kunci:

Sastra perjalanan, travel writing, flâneur, flânerie, Gabriel García Márquez. 


\section{Pendahuluan}

Sebuah karya sastra tidak berdiri secara otonom (Bertens, 2017). ${ }^{1}$ Dalam dunia kreasi, proses penciptaan karya berada dalam tegangan realitas kehidupan manusia. Bagi pengarangnya, proses mencipta mustahil dipisahkan dari realitas yang melingkupinya. Dalam telaah akademis, pembacaan terhadap sebuah karya sastra biasanya akan mengarah pada pengarang, karya sastra dan pembaca sehingga dimungkinkan pemaknaan yang dinamis terhadap sebuah karya sastra (Damono, 2011). Pengarang sebagai salah satu indikator pembacaan karya sastra kerapkali ditarik pada lingkup materi karya, inspirasi, imajinasi dan sebagainya. Singkatnya, bagaimana karya itu kemudian diciptakan menjadi salah satu pintu masuk dalam memahami karya sastra.

Galibnya, sumber pengkaryaan dihubungkan dengan pengalaman-pengalaman aktual pengarang (Jayanty, 2012). Tak jarang pengalaman tersebut akan mengilhami bentuk serta tema karya sastra yang dihasilkan. Sastra sendiri dapat dibedakan dari berbagai jenis tulisan lain, seperti tesis, berita, sejarah, biografi, laporan perjalanan, dan sebagainya. Tulisan-tulisan terakhir lebih menitikberatkan pada fakta objektif (Damono, 2011). Namun demikian, dalam khazanah sastra juga terdapat beberapa subgenre, seperti prosa sejarah, biografi, dan catatan perjalanan. Keragaman (genre) tersebut meneguhkan jika eksplorasi dalam sastra lingkupnya luas. Namun jenis-jenis karya sastra tersebut juga menjadi sumber ketegangan sehubungan dengan batasanbatasan antara fakta dan fiksi yang tampak menjadi kabur. Faruk (2013), misalnya, menyebut dunia yang dibangun sastra adalah jagad yang mungkin. Sedangkan Damono (2011) berargumentasi jika narasi karya sastra berada dalam hukum penciptaan, poetic license. ${ }^{2}$ Sebuah hak istimewa sastrawan dalam menggunakan mediumnya, yakni bahasa. Sastra dipahami sebagai olah kreatif pengarang dalam membengkokkan, membelokkan, dan bahkan merusak bahasa. Hal yang disebut terakhir berkaitan dengan prinsip fiksionalitas dan ekstrinsikalitas dalam telaah kesusastraan.

Salah satu subgenre sastra yang menempatkan fakta dan fiksi dalam tegangan eksplorasi adalah sastra perjalanan (travel writing). Seperti halnya novel sejarah, ${ }^{3}$ sastra perjalanan (juga disebut catatan perjalanan, travel writing) didasarkan pada pengalaman aktual pengarang dan menekankan aspek objektivitas. Seorang pengarang cerita perjalananmembuatkisah-kisahkelanaberdasarkan pengalaman konkret tatkala melancong ke suatu tempat. Fussel (1987) menyebut sastra perjalanan harus didasarkan pada pengalaman (perjalanan) nyata, bukan sekadar rekaan atau bersumber pada buku-buku dan cerita-cerita. Hal ini menjadi syarat sebuah tulisan dapat dikategorikan sebagai sastra perjalanan (Eder, 1981; Hagglund, 2000; Hulme \& Youngs, 2002; Vičič, 2011).

Pada prinsipnya sebuah perjalanan merupakan sebuah negosiasi antara diri (self) dan liyan (others) yang disebabkan pergerakan melampaui sekatsekat ruang dan waktu (Nasution, 2015). Jadi catatan perjalanan harus dipahami sebagai pelbagai jenis teks yang merekam perjumpaan self dan others sekaligus menegosiasikan kesamaan, kemiripan, dan keterbedaan yang berdimensi spasial dan temporal.

Sebagai terma, sastra perjalanan atau travel writing dipahami dalam konteks yang inklusif. Catatan yang berasal dari sebuah perjalanan tidak sekadar publikasi mengenai pengalaman seputar pengembaraan. Lebih jauh, sebuah lawatan yang menghasilkan dokumen sangat berkolerasi dengan perjalanan atau artefak kebudayaan (Thompson, 2011). Namun istilah travel writing harus pula disadari sebagai istilah generik bagi catatancatatan perjalanan. Sebuah subgenre yang merekam 
negosiasi antara diri dan liyan dan berorientasi untuk mendeskripsikan persamaan, keserupaan, keterbedaan (Mashlihatin, 2015).

\section{Jebakan Objektivitas dan Otientisitas Subjektif}

Secara subtansi, catatan perjalanan bertendensi pada sebuah kabar (informasi) dari pelbagai belahan dunia. Kenyataannya lokus kultural niscaya tidak statis melainkan dinamis. Sehingga perubahan atas pengalaman yang melintas jarak dan waktu menjadi inheren dalam teks perjalanan. Oleh sebab itu dunia yang dilukiskan dalam catatan perjalanan berupa perubahan yang menjadi bagian dalam narasi sehubungan dengan akurasi, objektivitas, serta memberikan imbas karena pada dasarnya sifat dari realitas adalah kompleks.

Catatan perjalanan menjadi inheren dari genre fiksi dari dunia referensial yang faktual (Cogeanu, 2014; Colbert, 2012; Thompson, 2011). Dalam tulisan objektif, seseorang akan mengambil jarak dengan dunia yang diamatinya. Sebaliknya, dalam pengamatan subjektif keintiman dan keterlibatan seseorang justru dapat memberikan detil-detil yang tidak dijumpai dalam tulisan objektif (Mashlihatin, 2015). Peristiwa-peristiwa yang dijumpai selama perjalanan setali dalam pembiasan melalui (1) kesadaran pengamatan penulis dan (2) tindakan penulisan, merger dari "pengalaman perjalanan" ke dalam "teks perjalanan". Proses tersebut terjadi secara selektif, dikurasi oleh pengarang untuk memprioritaskan beberapa bagian dan mengabaikan bagian lain. Preferensi pengarang tentunya sangat menentukan dalam proses seleksi. Sebagai imbas, akhirnya bentuk sastra perjalanan bertendensi melukiskan dunia yang parsial secara akurat dan sekaligus objektif (Mashlihatin, 2015).

Karena tendensinya, sastra perjalanan akan mendistorsi dunia dan menjelma ke dalam pandangan pengarang. Oleh sebabitu penggambaran dunia melalui kacamata seorang pelancong cenderung memiliki dua kutub berlawanan, yakni penggambaran objektif dan subjektif sekaligus. Objektivitas tampak dalam penyajian informasi yang dipersepsi oleh inderawi visual dan auditori. Penggambaran objektif biasanya akan membatasi narasi pengarang sebagai subjek, namun hal tersebut sengaja dilakukan demi membatasi kesan impresionistik dan/atau serupa anekdot. Sebaliknya, subjektifitas narasi perjalanan tersaji dalam hal-hal yang mengindikasikan keterlibatan diri, responrespon emosional, serta penilaian pengarang (Das, 2019). ${ }^{4}$ Kata kuncinya, strategi objektif mensyaratkan keberjarakan dan objektif menuntut keintiman penulis (Thompson, 2011). Objektivitas memang menjadi prinsip utama dalam subgenre ini. Sebab, selain hendak meyakinkan sidang pembaca, sastra perjalanan ingin menegaskan jika realitas yang diacunya adalah realitas yang berasal dari lokus serta budaya konkret bukan fiksi atau fabrikasi semata. Hal ini yang lantas membedakan dan menjadi kekhasan sastra perjalanan berbanding subgenre sastra lain, seperti novel sejarah, novel biografi, dan sebagainya.

Akar dari catatan perjalanan sejatinya tumbuh dan berkembang bersamaan dengan aktivitas kolonialisme Eropa (Ashcroft et al., 2013). Bagi Barat, semula Timur adalah "Narnia" yang jauh, penuh romansa, feminin, dan eksotis. Cerita-cerita seputar dunia berbeda akhirnya menyebar dan memberikan dorongan mental sekaligus panduan teknis bagi masyarakat Eropa untuk melakukan sebuah lawatan. Sebuah perjalanan yang berakhir pada pendudukan terhadap wilayah baru dan asing (Purwaningsih, 2015). Awal petaka bagi masyarakat luar Eropa.

Kolonialisme Barat senantiasa berupaya melakukan kontrol dan menundukkan Timur melalui pelbagai strategi. Kontrol dan penundukkan tersebut sehubungan dengan praktik kolonialisme yang terobesi untuk menanamkan sekaligus 
melestarikan sebuah kekuasaan atas tanah koloni (Atikurrahman, 2014). Kolonialisme sebagai penguasaan teritori mewujud dan melanggengkan dirinya dalam geograf kolonial melalui pelbagai cara, salah satunya melalui representasi Timur dalam wujud sebuah laporan perjalanan (travel report) yang terkesan objektif dan ilmiah.

Dalam wacana postkolonial, catatan perjalanan merupakan bagian integral dari praktik kolonialisme Barat. Travel text sebagai travel experience tak lain merupakan catatan perjalanan yang objektif dan subjektif sekaligus. Jenis teks ini menempatkan dirinya sebagai teks berjarak yang bertendensi mempertahankan keotientikan objek. ${ }^{5}$ Selain teks kolonialime objektif tersebut rupanya juga berkembang teks perjalanan subjektif. Hal ini didasarkan anggapan jika jenis teks terakhir lebih memberikan ruang eksplorasi, membuka kemungkinan, sekaligus keintiman dan sebagainya. Alhasil, teks yang dihasilkan dianggap jauh lebih otientik tinimbang teks objektif yang berjarak. Dari sini travelogues kemudian berkembang menjadi subgenre sastra yang akhirnya dikenal sebagai sastra perjalanan atau travel writing.

Genealogi sastra perjalanan identik dengan aktivitas kolonialisme (Ashcroft et al., 2013; Guillaume, 2011). Subgenre ini dipahami sebagai karya sastra yang seolah-olah hanya dapat ditulis oleh seorang pengarang Barat demi mengekalkan pengalaman mereka tentang Timur. Namun anggapan demikian dapat dipastikan keliru. Sebab sebuah pengembaraan merupakan bagian dari kebudayaan umat manusia tanpa peduli dari belahan mana mereka berasal. Sastra perjalanan juga ditulis oleh mereka yang berasal dari luar Dunia Pertama. Bahkan, penulisan kisah perjalanan oleh pengarang yang berasal dari Dunia Ketiga memberikan perimbangan atas bias dari representasi perjalanan yang selama ini monoton karena dimonopoli pengarang Barat.
Dalam tulisan ini akan diketengahkan sebuah cerita perjalanan yang ditulis oleh pengarang dari luar Dunia Pertama. Sebagai penegasan jika representasi yang dihadirkan pengarang Dunia Ketiga juga selevel dengan mereka yang berasal dari Eropa. Douze Contes Vagabonds (Dua Belas Dongeng Tentang Pengelana) yang dikarang oleh Gabriel García Márquez merupakan contoh yang relevan. Buku ini mengindikasikan catatan perjalanan seorang pengarang sastra yang bertutut tentang pengalaman seorang (self) pengelana dari Dunia Ketiga dalam menghayati pengalamannya selama melancong dan berjumpa dengan mereka (others) yang berasal dari Dunia Pertama, yakni manusia Eropa.

Douze Contes Vagabonds sebuah kumpulan berisi (dua belas) cerita pendek perjalanan yang diterjemahkan ke dalam bahasa Perancis dari buku asal dalam bahasa Spanyol, Doce Cuentos Peregrinos (Twelve Pilgrim Tales atau dalam edisi bahas Inggris diterjemahkan Strange Pilgrims). ${ }^{6} \quad$ Kisah-kisah kelana dalam kumpulan ini dapat dibaca sebagai pengalaman seorang Emigran yang berasal dari Amerika Latin (Vintage Books, 2006). Selain itu, ia juga dapat dihayati sebagai persepsi seorang individu Amerika Selatan di Eropa, dari seorang peraih Nobel, Gabriel García Márquez, yang galib dikenal sebagai penulis One Hundred Years of Solitude (1967) and Love in the Time of Cholera (1985).?

Dua belas cerita di sini menuturkan kisah manusia Amerika Latin yang terombang-ambing di Eropa: seorang ayah yang berduka di Roma untuk melakukan audiensi dengan Paus terkait anak gadisnya (The Saint, La Santa); seorang pejalan kaki yang menua menunggu kematian di Barcelona dengan seekor anjing yang dilatih untuk menangis di kuburannya (María dos Prazeres); seorang suami yang panik membawa istrinya ke rumah sakit di Paris untuk mengobati luka dan tidak pernah melihatnya lagi (The Trail of Your Blood in the Snow, 
El Rastro de tu Sangre en la Nieve); seoarang lelaki yang nelangsa dengan kesan pribadi ketika dia mendadak jatuh cinta dengan seorang wanita di bandara Paris pada pandangan pertama. Secara kebetulan perempuan tersebut menjadi teman seperjalanan dalam pesawat yang ditumpangi. Cerita ini mengungkapkan pemujaan voyeuristic (Sleeping Beauty and the Airplane, El Avión de la Bella Durmiente) (Pinguin Book, 1994).

Sebagai sebuah bunga rampai, Douze Contes Vagabonds merupakan kenangan nostalgia bagi mereka yang jauh dari rumah, rasa anonimitas di negeri asing, kerentanan yang menakutkan tatkala melangkah melewati ambang pintu ke dunia asing. Dua belas cerita tersebut merupakan pengalaman melancong ke Eropa yang ditulis oleh seorang pengarang Dunia Ketiga.

Dalam hal itu, memahami perjalanan sebagai sebuah gerakan kultural seharusnya tidak terjebak dalam pemaknaan sebagai pergeseran wadak (tubuh) seseorang yang melampaui batasbatas spasial dan temporal. Perjalanan memiliki dimensi spiritual. Dalam pelbagai kebudayaan dan agama perjalanan menjadi satu ritus tertentu yang menandakan suatu etape, seperti peristiwa hijrah seorang Muhammad dari Makkah ke Madinah atau isra' mi'raj dari Masjid Haram (Makkah) ke Masjid Aqsa (Jerusalem) dan berakhir di sidratul muntaha (arsy, langit atau khayangan). Dalam dunia sufi juga dikenal suluk (perjalanan spiritual) yang dilakukan seorang salik (pelancong, sufi). Juga, ziarah atau pilgrim, flâneur dan sebagainya. Pendek kata, perjalanan adalah inheren dalam aktivitas kebudayaan manusia. ${ }^{8}$

\section{Flânerie Sebagai Modus Operandi}

Dalam dunia kreatif melakukan perjalanan juga harus dipahami sebagai sebuah modus operandi: sebuah perjalanan (flânerie) - yang dapat diartikan sebagai nomadis secara fisik dan persepsi- dilakukan oleh seorang pengarang karya sastra berhubungan dengan proses kreatif berkarya (Boutin, 2012). Karsono (2021), misalnya, tatkala membaca metode kepengarangan Teguh Esha, pengarang trilogi Ali Topan, menjabarkan metode melancong (flânerie, tindakan berjalan-jalan atau mengembara) sudah kaprah dilakukan seseorang (flâneur) dengan tanpa tujuan lain selain menjadi pengamat yang gigih terhadap satu lingkungan sosial-kultur tertentu. ${ }^{9}$

Berangkat dari postulat Frisby (2015), Karsono mensinyalir jika bentuk-bentuk yang dilakukan selama flânerie antara lain menjelajahi pemandangan kota dengan berjalan kaki atau berkendaraan, mengamati segi-segi kehidupan kota, membaca teks, gambar, musik dan benda-benda, dan mencari ekstase melalui seks, narkoba atau agama. Flânerie memberikan dorongan, inspirasi dan bahan bagi seorang flâneur untuk menciptakan segala macam karya, mulai dari musik, sastra dan seni hingga ritual, drama, tari dan film. Dalam Douze Contes Vagabonds Márquez yang berkedok sebagai seorang flâneur membiarkan dirinya mengembara dan sekaligus melakukan counter-travelling sebelum akhirnya mengungkapkan pandangan, nilai, keprihatinan, dan pengalaman tentang kotakota di Eropa.

Gabriel García Márquez sendiri merupakan seorang penulis kelahiran Kolombia yang lebih banyak tinggal di Meksiko dan Eropa. Ia menulis banyak novel serta cerita pendek. Pola hidup nomaden yang dilakukannya tampak dalam representasi karya sastra yang digubahnya. Awal karirnya dimulai sebagai seorang wartawan untuk harian Bogotá, El Espectador dan belakangan ia bekerja sebagai koresponden asing di Roma, Paris, Barcelona, Carasa, hingga New York.

Dalam prolog Douze Contes Vagabonds Márquez menulis jika cerita-cerita perjalanan dalam bunga rampai tersebut didasarkan pada perjalanannya 
ke Roma, Barcelona, Jenewa, dan Paris. Dia juga menyebutkan jika pada setiap cerita yang ditulisnya tidak lupa dicantumkan waktu kejadiannya. Salah satu karakter cerita pendek dengan catatan waktu kejadian tersebut dapat dalam Bon Voyage Monsieur Le Président (Selamat Melakukan Perjalanan Bapak Presiden). Cerita pendek ini bercerita tentang seseorang yang melakukan perjalanan dari Martinique ke Jenewa. Di sana ia menemui orangorang yang berasal dari rumpun yang sama dengan dirinya, Meksiko sebagai bagian dari Amerika Latin. Meskipun dibalut dalam karangan fiksi, hal itu tidak terlepas dari latar pengarang yang tinggal di Meksiko dan melakukan perjalanan ke beberapa tempat di Jenewa. Bahkan dalam narasi dan dialognya, Márquez dapat menggambarkan suasana Swiss pada saat pertama kali ia berkunjung ke sana dan selanjutnya memiliki kenyataan yang berbeda.

Jikamerujukpada prinsiputamasastraperjalanan yang mengungkapkan budaya asal penulis dan atau budaya daerah yang diceritakan di dalam teks, Bon Voyage Monsieur Le Président dapat dikategorikan sebagai sebuah sastra perjalanan (dari seorang dari Dunia Ketiga yang merepresentasikan Dunia Pertama). Seperti disebutkan di atas, sastra perjalanan atau travel writing adalah segala bentuk catatan yang merekam pertemuan antara diri dan liyan yang disertai negosiasi-negosiasi atas perbedaan atau persamaan yang melingkupinya. Sehingga seorang pelancong (traveler) yang tengah berkelana dimungkinkan bertemu penduduk setempat atau hal-hal lainnya di tengah jalan.

Harahap (2009) menyebut catatan perjalanan yang baik sebaiknya menawarkan kepada pembaca lebih dari sekadar deretan kesan. Dalam narasinya seyogyanya juga mampu menemukan cerita (yang dilakoni oleh pengarang dan orang-orang yang dijumpainya), pikiran dan perasaan dari tokohtokoh tersebut, dan sebuah gagasan besar tentang kehidupan yang ingin disampaikan oleh pengarang. sehingga dapat diketahui sastra perjalanan dapat disajikan tidak hanya berupa laporan perjalanan, tetapi juga dapat berbentuk tulisan lain sehingga dapat dimasukkan dalam kategori travel notes. Seperti yang diungkapkan Raban (1987) sastra perjalanan juga meliputi privat diary, esai, cerpen, prosa lirik, catatan kapten kapal, dan catatancatatan yang ditulis selama perjalanan dalam pelbagai bentuk.

Sebelum terurai lebih lanjut, berikut akan dijabarkan senarai konseptual sastra perjalanan (travel writing) dalam usaha membaca Bon Voyage Monsieur Le Président. Tulisan ini mengambil teladan dari teori travel writing yang dirumuskan oleh Carl Thompson (2011) dalam Travel Writing. Thompson menjelaskan sejarah sastra perjalanan kali pertama munculsudah sejakdarizaman kuno dan hingga masa sekarang masih terus berkembang. Dia menegaskan jika sastra perjalanan tidak hanya menyajikan laporan perjalanan dengan polos, padat, dan ringkas seperti yang dilakukan Addison dalam Remarks on Saveral Part of Italy (1705). Sastra perjalanan juga melakukan penilaian atas pengalaman hidupnya serta pelbagai hal yang dirasakan agar narasi yang dituliskan lebih ekspresif dan estetis. Thompson menyebut A Tramp Abroad (1880) yang ditulis Mark Twain telah menandai perubahan strategi dalam penulisan jenis ini.

Dalam sastra perjalanan pembaca disuguhkan informasi tentang kebudayaan di luar dirinya, juga interaksi antara self dengan other, dan sebagainya. Untuk membangun gambaran hasrat diri, pengarang biasanya menggunakan sebuah cara diskriminatif yang menganggap tempat yang dikunjungi, budaya yang dijumpai, serta individu saat mereka berinteraksi sebagai "others". Untuk merepresentasikan yang lain, travel writer menjadikan mereka sebagai proyek formasi identitas dan kemajuan terhadap diri mereka sendiri (Edwards \& Graulund, 2011; Holland \& Huggan, 
1998; Lindsay, 2015; Lisle, 2006; Pratt, 2008). Liyan yang digunakan pengarang cerita perjalanan semata demi mendefinisikan keunikan dan superioritas mereka, juga kemungkinan orang-orang yang berasal dari kultur mereka sendiri. Strategi lain yang sering digunakan untuk mempromosikan diri yaitu dengan mengkontraskan diri dengan pelancong lain yang dijumpai selama perjalanan. Pelancong lain kemudian dianggap sebagai turis (pelancong biasa), sedangkan dirinya akan menggambarkan dirinya sebagai pengelana yang tepat, yang semestinya.

Jika dikaitkan dengan wacana poskolonial, terdapat dua pengelompokan yang harus dipahami sehubungan dengan sastra perjalanan. Pertama, tulisan yang dibuat oleh orang-orang dari wilayah koloni; kedua, tulisan yang digubah orang-orang dari wilayah koloni. Contoh dari kajian pada kelompok pertama tampak dalam kajian yang dilakukan Lisle (2006) dalam The Global Politics of Contemporary Travel Writing. Pada tulisannya tersebut ditemukan bahwa sastra perjalanan turut berpartisipasi dalam menyebarkan dan memuluskan tujuan imperialisme dengan menekankan gagasan berbagai ketidaksetaraan dan melegitimasi relasi-relasi eksploitatif yang tercipta karena sistem kolonial.

Sementara itu, dalam travel writing yang ditulis orang-orang dari wilayah yang dikoloni biasanya akan ditemukan strategi manipulasi terhadap teks dalam rangka menyusun kembali, mensubversi dan menulis kembali bentuk-bentuk imperialisme. Sehingga mereka berada pada dua kaki antara bentuk yang dipengaruhi Barat sekaligus upaya subversi atasnya (Akmal, 2014). Dalam tulisan ini dua belas cerita dalam Douze Contes Vagabonds dapat dikategorikasi sebagai travel writing jenis kedua karena Gabriel García Márquez seperti diketahui berasal dari Kolombia, wilayah Amerika Latin yang menjadi wilayah koloni Spanyol. Selain itu, yang menarik dari cerita-cerita dalam bunga rampai cerita pendek ini, bahwa yang diceritakan adalah pengalaman perjalanan yang berlatar Eropa. Sehingga tindak penulisan dalam buku ini dapat dikategorikan sebagai upaya couter-travelling.

\section{Bon Voyage Monsieur Le Président!}

Pada bagian ini akan dianalisis bagian-bagian dari cerita pendek yang menunjukkan karakteristik sastra perjalanan serta mengidentifikasi self dan others yang berusaha ditunjukkan oleh pengarang sebagai upaya representasi atas perjalanannya ke Jenewa.

Dalam prolognya Márquez mengungkapkan secara eksplisit motif penulisan cerita-cerita yang terkumpul dalam Douze Contes Vagabonds (1992), yakni berdasarkan perjalanannya ke Eropa selang dua puluh tahun silam. Oleh sebab itu, untuk menguji sekaligus membuktikan ingatannya masih bagus, serta karya yang dihasilkan benar-benar sesuai dengan pengalamannya, Márquez memutuskan untuk melakukan perjalanan ke beberapa tempat di Eropa, seperti Paris, Barcelona, Jenewa, dan Roma.

“Comme j'avais décrit les différentes villes d'Europe où ils se déroulent en faissant appel à ma mémoire et de loin, j'ai voulu mettre à l'épreuve la fidélité de souvenirs vieux de Presque vingt ans, et j'ai fait un rapide voyage de reconnaissance à Barcelone, Genève, Rome, et Paris." (p. 10-11)

(Karena yang saya jelaskan adalah berbagai kotakota Eropa di mana mereka mengingangatkan pada memori saya sejauh ini, sekaligus saya ingin menguji kesetiaan kenangan yang hampir dua puluh tahun, maka saya melakukan perjalanan cepat di Barcelona, Jenewa, Roma, dan Paris.)

Namun dalam perjalanan kedua, pengarang justru menemukan semua keadaan Eropa telah berubah. Kontras dengan yang ia temui dua puluh tahun silam. Hal ini menunjukkan jika penulis (self) telah menemukan bentuk liyan (other) dari dirinya. Perbedaan ini tidak hanya terjadi karena perjalanan 
yang bersifat fisik saja, tetapi juga perjalanan waktu yang membawanya ke tempat yang sama, tetapi dengan keadaan yang berbeda. Hal ini memunculkan negosiasi-negosiasi yang dilakukan oleh diri ketika berada di lingkungan yang melingkupinya.

"Ni les unes ni les autres n'avaient plus rien à voir avec le souvenir que j'en avais. Toutes, de même que toute l'Europe aujourd'hui, étaient rendues étranges par une suprenante inversion" (p. 11)

(Baik satu atau yang lain tidak ada hubungannya dengan memori saya. Semua, serta seluruh Eropa hari ini menjadi aneh secara mengejutkan.)

Kedua, pengalaman nyata (lawatan kedua ke Eropa) tersebut dituangkan pada salah satu cerita, Bon Voyage Monsieur Le Président. Cerita pendek ini berkisah tentang seorang presiden yang menjadi korban kudeta militer di negaranya. Dia berkunjung ke Jenewa untuk kali kedua dikarenakan hendak melakukan pengobatan setelah beberapa waktu diasingkan di Martinique. Lantas Eropa yang ditemukan oleh tokoh Presiden pada perjalanannya tersebut sangat berbeda dengan perjalanan sebelumnya, tatkala kali pertama menjejakkan kakinya di Jenewa sebagai seorang presiden.

"Lors de son premier séjour à Genève le lac était diaphane et serein, les mouettes, paisibles, venaient picorer dans sa main et les filles de joie paraissent des sylphides de six heures du soir avec leurs volants d'organdi et leurs ombrelles en soie. À présent, aussi loin que portait sa vue, la seule femme accessible était une marchande de fleures sur le quai désert." (p. 13)

(Selama pertama kali tinggal di Jenewa danau itu begitu transparan dan tenang, ada burung camar, damai mematuk-matuk di tangannya dan pelacur muncul pada pukul enam malam dengan kain organdi dan payung sutra. Sekarang sejauh pandangannya, yang ada hanyalah satu-satunya wanita yang merupakan seorang pedagang bunga pada platform sepi)
Dalam narasi tersebut tampak jika pengarang hendak menggambarkan keadaan orang-orang dan budaya dari tempat yang dikunjungi. Kemudian pengarang membandingkannya dengan sensasi yang ia miliki sebelumnya, yaitu kenangan tentang Jenewa dua puluh tahun silam. Jarak temporal tersebut tidak hanya menimbulkan kesan keterasingan, tetapi juga jarak dan kemuraman yang berhasil diciptakan oleh pengarang. Hal ini yang membedakan antara catatan perjalanan yang bersifat fiksi dan bersifat ilmiah, seperti halnya sebuah laporan perjalanan yang terkesan kaku.

"Sur le pont du Mont-Blanc, l'on baissait en toute hâte les drapeaux de la Confédération pris de folie dans la bourrasque, et l'élégant jet d'eau couronné d'émbruns séteignit plus tôt que de coutume. Le president ne reconnut pas son café habituel sur le quai car on avait relevé l'auvent de toile verte et fermé le terasses estivales bordées de fleurs." (p. 15)

("Di atas jembatan Mont Blanc, bendera Konfederasi segera diturunkan karena badai yang mengamuk, dan air jet semprot elegan yang dimatikan lebih awal dari biasanya. Presiden tidak mengenali kafé yang biasa ada di dermaga seperti yang terdapat tenda hijau dan ditutup pada teras pada musim panas dilapisi dengan bunga.)

Kutipan tersebut sekaligus menunjukkan bagaimana pengarang dapat menjelaskan keadaan tempat yang ia kunjungi. Melalui narasi tersebut diasumsikan pengarang mencoba mengilustrasikan negara-negara yang pernah menjadi jajahan Eropa. Prancis, misalnya, melalui bendera konfederasi yang masih berkibar. Padahal bekas jajahan mereka telah sepenuhnya berdaulat. Akan tetapi kenyataannya mereka masih berada di bawah bayang-bayang konfederasi yang diciptakan Prancis. Tidak hanya menceritakan keadaan tempat yang dikunjungi, Márquez juga menceritakan Martinique sebagai representasi budaya dan dirinya. 
"Il avait tout le temps de l'exil à la Martinique. Au mois d'août la chaleur était insupportable, et jusqu'á midi il demeurait dans son hamac à lire sous le murmure des pales du ventilateur de sa chamber à coucher." (p. 28) (Diamenghabiskanwaktupengasingan di Martinique. Pada bulan Agustus panas tak tertahankan, dan sampai dua belas siang ia tetap di tempat tidur gantung untuk membaca dalam gumaman dengan angin dari ventilasi di kamar tidurnya)

Selain menggambarkan keadaan fisik maupun suasana yang berkaitan dengan nostalgia, Márquez juga menceritakan orang-orang yang ditemuainya ketika perjalanan melalui tokoh Homero dan Lazara. Kedua tokoh ini juga merupakan pendatang dari Amerika Latin, tepatnya Meksiko dan Puerto Rico. Di sini dapat dilihat bahwa pengarang merepresentasikan liyan (others) bukan hanya dalam sosok orang-orang Eropa sebagai penduduk setempat, melainkan orang-orang yang serumpun dengannya, orang-orang Latin. Hal ini sesuai dengan konsep sastra perjalanan sebagai upaya untuk menunjukkan superioritasnya. Seorang pengarang yang bermodus melancong juga menggunakan orang-orang yang berasal dari kultur mereka sendiri. Meskipun dua tokoh tersebut menjadi bagian dari negara Eropa dengan bertempat tinggal di sana, hal ini tidak menjadikan posisi mereka sama dengan Eropa. Hal ini tampak ketika dua tokoh itu dimunculkan oleh pengarang sebagai keluarga yang miskin.

"il l'avait vu acheter un pardessus de semi-saison à col de faux vison, non pas dans les boutiques illumines de la rue Rhône où les émirs de passage faisaient leur courses mais au marché aux puces." (p. 24)

(ia melihatnya membeli mantel semi-musim kerah bulu palsu, bukan di toko-toko yang menerangi jalan Rhône mana para emir (bangsawan) berbelanja, tetapi di pasar loak)
Jika dikaitkan dengan wacana postkolonial, dapat diasumsikan pengarang tengah menunjukkan imperialisme yang telah dilakukan oleh Eropa. Diasumsikan seperti ini mengingat sebagian besar wilayah Amerika Latin, termasuk Martinique, merupakan bekas jajahan Prancis yang sampai dengan saat ini masih berada di bawah departemen Prancis. Cerita Márquez ini merupakan salah satu contoh sastra perjalanan yang ditulis oleh seorang pengarang dari negara bekas koloni. Sebagai yang pernah dikoloni, pengarang berada pada dua halyang dapat dipisahkan yaitu selain berusaha melakukan inversi, mereka juga tidak dapat lepas dari pengaruh Eropa. Hal ini diungkapkan pengarang di bagian akhir cerita bahwa akhirnya tokoh Presiden memilih untuk kembali ke asalnya, Martinique dan berkontribusi di sana untuk kemajuan bangsanya. Namun ia tidak dapat memungkiri pengalaman yang didapatkan selama tinggal di Jenewa merupakan takdir yang menyenangkan.

"le veritable motif de sa letter était de leur confier qu'il était tenté de rentrer au pays afin de prendre la tête d'un movement rénovateur pour une cause juste et une patrie digne, ou ne fût-ce que pour la simple gloire mesquine de ne pas mourir de vieillesse dans son lit. En ce sens, concluait-il, son voyage à Genève avait été providentiel." (p. 37)

(alasan yang benar dari suratnya adalah untuk memberikan mereka bahwa ia berusaha untuk kembali ke negaranya untuk mengambil bagian sebagai kepala gerakan renovasi agar tanah air menjadi layak, atau jika hanya untuk kemuliaan kecil yang sederhana, ia tidak mati tua di tempat tidurnya Dalam hal ini, ia menyimpulkan perjalanannya ke Jenewa adalah takdir yang menyenangkan.)

Dengan demikian dapat dilihat bahwa sebagai bagian yang pernah terjajah, meskipun berusaha untuk melakukan subversi, mereka juga tidak dapat lepas dari pengaruh Eropa. 


\section{Kesimpulan}

Berdasarkan pembahasan di atas, dapat disimpulkan catatan perjalanan Gabriel García Márquez dalam Bon Voyage Monsieur Le Président dapat dikategorikan sebagai salah satu contoh sastra perjalanan. Sastra perjalanan yang baik tidak hanya menyajikan laporan perjalanan yang polos, kaku, rigid dan ilmiah. Dalam narasi perjalanan seorang pengarang juga dituntut untuk menyuguhkan cerita yang menarik kepada sekalian pembaca mengenai kehidupan orang-orang yang ditemuinya, budaya dan memberikan pandangan pribadinya. Persepsi subjektif ini dapat menjadi satu cara untuk mengungkapkan diri (self) yang dihadirkan pengarang dalam sebuah karya sastra. Jika dikaitkan dengan kajian poskolonial, karya ini dapat dikategorikan sebagai sastra perjalanan yang ditulis oleh kelompok yang terjajah, mengingat Martinique merupakan bekas jajahan Prancis. Dalam menuliskan ceritanya, keinginan pihak terjajah untuk melakukan subversi terhadap imperialisme Eropa. Sebab pada pada hakikatnya mereka belum sepernuhnya lepas dari belenggu kolonialisme bangsa yang pernah menjajahnya.

\section{Daftar Pustaka}

Akmal, R. (2014). Sastra Perjalanan. Retrieved from https://docplayer.info/63427530-Travel-writing-glorifikasiatas-imajinasi.html

Ashcroft, B., Griffiths, G., \& Tiffin, H. (2013). Post-colonial studies: The key concepts. In Post-Colonial Studies: The Key Concepts. https://doi.org/10.4324/978023777855

Atikurrahman, M. (2014). Prosa, Ruang, dan Kota Pascakolonial. Poetika, 2(2), 137-147. https://doi.org/10.22146/ poetika.v2i2.10445

Berger, P., \& Luckmann, T. (2016). The social construction of reality. In Social Theory Re-Wired: New Connections to Classical and Contemporary Perspectives: Second Edition. https://doi. org/10.4324/9781315775357

Bertens, H. (2017). Literary theory: The basics. In Literary Theory: The Basics. https://doi. org/10.4324/9780203488836

Boutin, A. (2012). Rethinking the Flâneur: Flânerie and the Senses. Dix-Neuf, 16(2). https://doi.org/10.1179/ dix.2012.16.2.01

Britannica, T. E. of E. (2007, September). Poetic license. Encyclopedia Britannica. Retrieved June 10, 2021, from https://www.britannica.com/art/poetic-license

Cogeanu, O. (2014). What Makes Travel Literature? The International Journal Of Humanities \& Social Studies , 2(6), 1-4. Retrieved from https://www.researchgate.net/publication/267097382_What_Makes_ Travel_Literature

Colbert, B. (2012). Travel Narrative. In The Encyclopedia of Romantic Literature. https://doi. org/10.1002/9781118300916.wberlt014

Damono, S. D. (2011). Pengarang, Karya Sastra dan Pembaca. LiNGUA: Jurnal Ilmu Bahasa Dan Sastra, 1(1). https://doi.org/10.18860/ling.vli1.540

Das, N. (2019). Perspectives on Travel Writing. In N. Das \& T. Youngs (Eds.), The Cambridge History of Travel Writing (pp. 299-580). https://doi.org/10.1017/9781316556740

Eder, D. L. (1981). Getting Away From It All. Retrieved June 9, 2021, from VQR: A National Journal Of Literature \& Discussion website: https://www.vqronline.org/getting-away-it-all 
Edwards, J. D., \& Graulund, R. (2011). Introduction: Reading Postcolonial Travel Writing. In Postcolonial Travel Writing. https://doi.org/10.1057/9780230294769_1

Faruk, F. (2013). Pengantar Sosiologi Sastra: Dari Strukturalisme Genetik Sampai Post-Modernisme (Pustaka

Pe). Yogyakarta.

Frisby, D. (2015). The flâneur in social theory. In The flaneur (Vol. 23, pp. 81-110). https://doi. org/10.4324/9781315765389

Fussel, P. (1987). The Norton Book Of Travel. New York: W.W. Norton.

Geetha, B. J. (2010). Magic Realism in Gabriel Garcia Marquez's One Hundred Years of Solitude. Rupkatha Journal on Interdisciplinary Studies in Humanities, 2(3). https://doi.org/10.21659/rupkatha.v2n3.13

Glattfelder, J. B. (2019). The Consciousness of Reality. https://doi.org/10.1007/978-3-030-03633-1_14

Guillaume, X. (2011). Travelogues of difference: IR theory and travel literature. Alternatives, 36(2). https://doi. org/10.1177/0304375411409016

Hagglund, E. (2000). Tourists and Travellers: Women's Non-Fictional Writing About Scotland 1770-1830 (The

University of Birmingham). Retrieved from https://core.ac.uk/download/pdf/9837555.pdf

Harahap, M. (2009, September 30). Tentang Travel Writing: Tulisan Kisah Perjalanan atau Sastra Perjalanan.

Retrieved June 9, 2021, from Diskusi “Tentang Travel Writing” bersama Hari Kunzru, Forum

Indonesia Membaca website: https://mulaharahap.wordpress.com/2009/09/29/tentang-travel-writingtulisan-kisah-perjalanan-atau-sastra-perjalanan/

Holland, P., \& Huggan, G. (1998). Tourists with Typewriters: Contemporary Reflections on Contemporary Travel Writing. . Ann Arbor: University of Michigan Press.

Hulme, P., \& Youngs, T. (2002). The Cambridge Companion to Travel Writing. In The Cambridge Companion to Travel Writing. https://doi.org/10.1017/ccol052178140x

Jayanty, D. I. (2012). Unsur-Unsur Kriminalitas Novel Di Atas Mahligai Cinta Karya Sri Rokhati : Tinjauan

Sosiologi Sastra Dan Implementasinya Dalam Pembelajaran Sastra Di SMA (Universitas

Muhammadiyah Surakarta). Retrieved from http://eprints.ums.ac.id/19262/

Karsono, S. (2021). Flâneur, Popular Culture and Urban Modernity: An Intellectual History of New Order

Jakarta. Asian Studies Review, 45(2). https://doi.org/10.1080/10357823.2020.1784092

Kuntowijoyo. (2004). Sejarah / Sastra. Humaniora, 16(1), 17-26. https://doi.org/https://doi.org/10.22146/jh.803

Lindsay, C. (2015). Travel Writing and Postcolonial Studies. In C. Thompson (Ed.), The Routledge Companion to

Travel Writing. https://doi.org/10.4324/9780203366127-12

Lisle, D. (2006). The Global Politics of Contemporary Travel Writing. https://doi.org/10.1017/CBO9780511491535

Márquez, G. G. (1992). Douze Contes Vagabonds. Paris: Grasset.

Márquez, G. G. (1994). Strange Pilgrims: Twelve Stories. London: Penguin Books Ltd.

Márquez, G. G. (2006). Strange Pilgrims: Twelve Stories. New York: Vintage Books.

Márquez, G. G. (2021). Para Peziarah yang Janggal (Strange Pilgrims). Jakarta: Gramedia Pustaka Utama.

Mashlihatin, A. (2015). Penggambaran Dunia dalam Novel Perjalanan 99 Cahaya Di Langit Eropa. Poetika, 3(1). https://doi.org/10.22146/poetika.v3i1.10427

Muhtarom, I. (2014). Realisme Magis dalam Cerpen: Kasus Cerpen Gabriel García Márquez, Triyanto Triwikromo, Dan A.S. Laksana. Poetika, 2(2). https://doi.org/10.22146/poetika.v2i2.10444 
Nasution, A. A. (2015). Gambaran Diri Andrea Hirata Dalam Novel Edensor: Konsep Travel Writing Carl Thompson. Poetika, 3(1). https://doi.org/10.22146/poetika.v3i1.10425

Pratt, M. L. (2008). Imperial Eyes Travel Writing and Transculturation. London: Routledge.

Purwaningsih, N. S. (2015). Subjektivitas dalam Cerita Perjalanan Novel Lumbini Karya Kris Budiman.

Poetika, 3(1). https://doi.org/10.22146/poetika.v3i1.10432

Raban, J. (1987). Coasting. London: Picador.

Ratner, C. (2002). Subjectivity and objectivity in qualitative methodology. Forum Qualitative Sozialforschung,

3(3). https://doi.org/10.17169/fqs-3.3.829

Robinson, L. (2013). Gabriel García Márquez and Ovid: Magical and Monstrous Realities (NED-New edition).

Retrieved from https://www.jstor.org/stable/10.7722/j.ctt24hfs8

Said, E. W., \& Fawaid, A. (2010). Orientalisme: Mengugat Hagemoni Barat dan menduduki Timur sebagai subjek. Yogyakarta: Pustaka Pelajar.

Sie, H. (2020). Realisme Magis dalam Novel Seratus Tahun Kesunyian Karya Gabriel Garcia Marquez

Berdasarkan Konsep Karakteristik Realisme Magis Wendy B. Faris. Sekolah Tinggi Filsafat

Katolik Ledalero, Maumere.

Thompson, C. (2011). Travel Writing. London: Routledge.

Vičič, Š. G. (2011). Native and foreign places in travel writing: The Guardian travel section. In M. Brdar, M.

Omazic, \& V. P. Takac (Eds.), Space and Time in Language. Berlin: Peter Lang.

1. Pembicaraan terkait tegangan antara realitas dan persepsi subjek tidak hanya terjadi dalam ranah kesusastraan, dalam kajian humaniora yang dianggap lebih objek silang pendapat antara keduanya kerapkali menimbulkan diskusi yang bisa disebut membingungkan. Lih. James B. Glattfelder (2019), The Consciousness of Reality atau Peter L. Berger (2016), The Social Construction of Reality.

2. Dalam Encyclopaedia Britannica (Britannica, 2007) Poetic license dipahami sebagai, "the right assumed by poets to alter or invert standard syntax or depart from common diction or pronunciation to comply with the metrical or tonal requirements of their writing." As a general rule, poetry has a carefully controlled verbal structure. The metre of the poem, the pattern of stressed and unstressed syllables, and the sounds and modulations of the words themselves all affect the subtle meanings and feelings that the poet may be trying to convey or evoke. Poets may distort normal prose patterns for the sake of form and therefore assume poetic license; it is solely a matter of aesthetic judgment and sensibility as to whether the alterations enhance or detract from the total effect of the poem. The term poetic license is also sometimes used in a humorous or pejorative sense to provide an excuse for careless or superficial writing.

3. Pembicaraan lebih rigid terkait sastra dan sejarah (sastra bernilai sejarah) dapat dibaca pada tulisan Kuntowijoyo (2004), Sejarah / Sastra.

4. Ulasan mengenai perbedaan antara sudut pandang objektif dan subjektif dapat dibaca dalam artikel Carl Ratner (2002) Subjectivity and Objectivity in Qualitative Methodology.

5. Namun perlu dicatat, objektivitas bukanlah sebuah terma yang netral. Dalam konteks kolonialisme Edward Said (2010) menulis dalam Orientalisme, jika cara pikir Barat terhadap Timur disusun secara 
sistematis dan sedemikian rupa, lantas disebarkan secara luas melalui lembaga-lembaga pendidikan Eropa. Sehingga bisa dikatakan sesuatu yang ilmiah tidak lepas dari bias subjek tertentu.

6. Lih. dalam edisi Bahasa Inggris yang diterbitkan oleh Vintage (2006) dan Penguin (1994), atau dalam edisi Bahasa Indonesia yang diterjemahkan Para Pengelana yang Janggal (Strange Pilgrims) (2021).

7. One Hundred of Sulitude edisi bahasa Inggris dari versi asli edisi Spanyol-Amerika, Cien años de soledad dan terbit kali pertama pada 1967. Novel ini dianggap sebagai masterpiece seorang Gabriel García Márquez dan mengantarnya sebagai peraih Nobel Sastra (1982). Melalui novel ini juga Márquez dianggap sebagai peneroka dalam gaya narasi novel yang dikenal sebagai realisme-magis(Geetha, 2010; Robinson, 2013; Sie, 2020) (Geetha, 2010; Muhtarom, 2014; Robinson, 2013; Sie, 2020). Sedangkan Love in the Time of Cholera dalam versi asli (Spanyol) berjudul El amor en los tiempos del cólera (1985) adalah novel yang lain.

8. Bandingkan dengan ulasan Purwaningsih (2015) mengenai situs Taman Suci Lumbini yang dikeramatkan oleh umat Buddha di Nepal. Lumbini diyakini oleh umat Buddha sebagai tempat kelahiran Buddha Gotama.

9. Dalam Wikipedia terma flâneur dipahami sebagai "...an ambivalent figure of urban affluence and modernity, representing the ability to wander detached from society with no other purpose than to be an acute observer of industrialized, contemporary life". Flânerie sebagai modus operandi dalam proses kreatif (sastra) dapat ditemukan dalam sosok seorang Charles Baudelaire, sebagaimana disebutkan oleh Walter Benjamin. 